\title{
Fundus changes in mesangiocapillary glomerulonephritis type II: clinical and fluorescein angiographic findings
}

\author{
J DUVALL-YOUNG, ' C D SHORT, ? M F RAINES,' R GOKAL, AND \\ W LAWLER
}

From the 'Department of Ophthalmology, 'Department of Renal Medicine, and 'Department of Pathology, University of Manchester.

SUMmaRY Previously we have demonstrated a deposit in Bruch's membrane in a single case of mesangiocapillary glomerulonephritis type II. We studied a group of patients with this disease and described extensive clinical and fluorescein angiographic abnormalities, which were in marked contrast to the findings in a group of patients with other forms of glomerulonephritis. This finding contributes to our understanding of the pathophysiology of the complex of the retinal pigment epithelium, Bruch's membrane, and choriocapillaris.

A comparison can be made between the anatomy of the glomerulus and the choriocapillaris-Bruch's membrane-retinal pigment epithelium complex, in which the choriocapillaris is likened to the glomerular tuft, Bruch's membrane to the glomerular basement membrane, and the retinal pigment epithelium to the glomerular epithelium.'

In a previous case report of a patient with type II mesangiocapillary glomerulonephritis (MCGN) we have demonstrated the occurrence of deposits in the choriocapillaris and Bruch's membrane which have the clinical appearance of drusen but the histopathological characteristics of deposits in the glomerulus. ${ }^{2}$ In type II MCGN, which is frequently associated with partial lipodystrophy (PLD), deposits of electron dense material, often with a ribbon like appearance, are found within the glomerular basement membrane. ${ }^{3}$ This is in contrast to the discrete deposits found in (a) membranous nephropathy, where the material lies initially between the basement membrane and the epithelium; $(b)$ in type I MCGN, where the deposit is predominantly subendothelial between the basement membrane and the endothelium; and $(c)$ in mesangial proliferative glomerulonephritis, where the majority of the deposits are in the mesangium ${ }^{4}$ (Fig. 1).

We have therefore examined clinically the eyes of

Correspondence to J Duvall-Young, FRCS, Walton Hospital, Rice Lane, Liverpool L9 1AE. patients with a variety of glomerular disorders, including further cases of type II MCGN and partial lipodystrophy (PLD), and report our findings.

\section{Methods and patients}

From the diagnostic index at the Manchester Royal Infirmary Renal Unit we selected for ophthalmic investigation 17 patients with biopsy proved glomerular disease and two further patients with PLD but who had never had a renal biopsy. The histological diagnosis was withheld from the ophthalmologists who examined the patients by routine clinical methods, fundus photography, and fundus fluorescein angiography. All the patients were normotensive and had been so for some months, though many had had a period of hypertension earlier in the course of their illness. Patients 4,7 , and 13 had reached end stage renal failure and had had successful renal transplantation at the time of the study. No patient was receiving dialysis.

Details of the patients are given in Tables 1, 2, and 3 .

\section{Results}

None of the patients had ocular symptoms. All the anterior segments appeared normal and no hypertensive retinopathy was detected. 


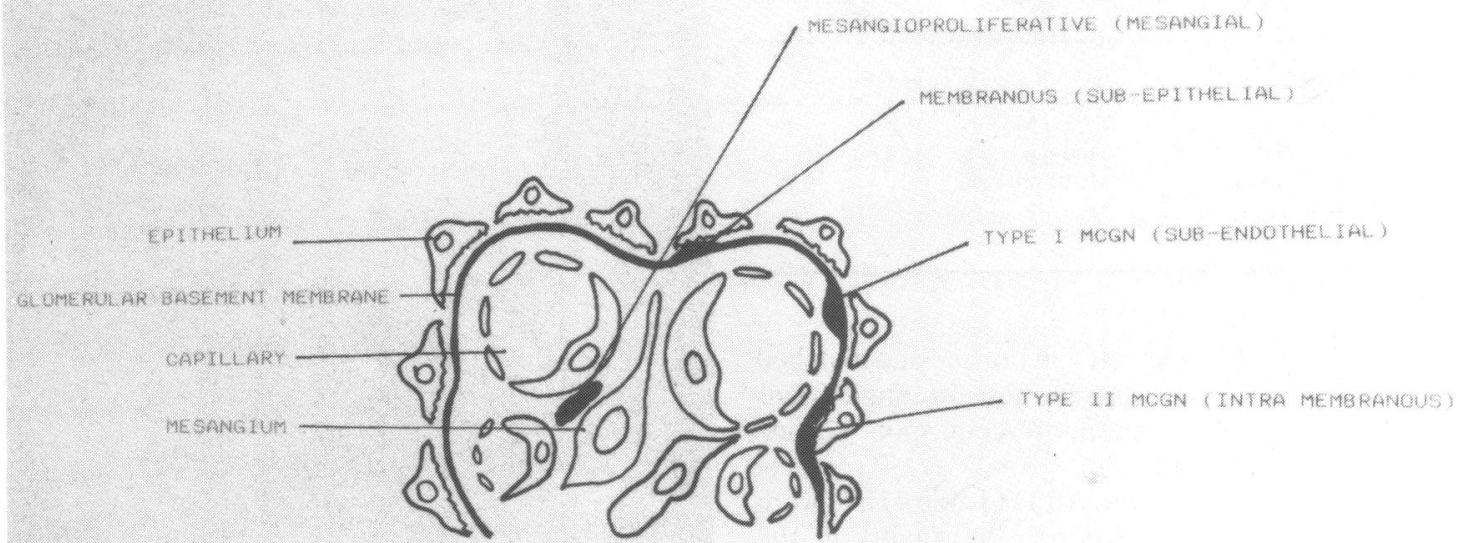

Fig. 1 Predominant sites of deposition of immunoreactive and electron-dense material in various glomerulopathies.

Of the 12 patients without PLD six had type I MCGN, one had minimal change disease (a term used by renal pathologists to describe a nephritis in which there is no evidence of disease on light microscopy), and five had membranous nephropathy.

Table 1 Clinical details of cases with PLD

\begin{tabular}{|c|c|c|c|c|c|c|}
\hline $\mathrm{Ca}$ & $\begin{array}{r}\text { se Age } \\
(y r)\end{array}$ & Sex & $\begin{array}{l}\text { Glomerular } \\
\text { disease }\end{array}$ & $\begin{array}{l}\text { Time since } \\
\text { diagnosis } \\
(y r)\end{array}$ & $\begin{array}{l}\text { Blood } \\
\text { pressure } \\
(\mathrm{mm} \mathrm{Hg})\end{array}$ & $\begin{array}{l}\text { Current } \\
\text { medication }\end{array}$ \\
\hline 1 & 43 & $\mathbf{M}$ & MCGN II & $0 \cdot 6$ & $140 / 90$ & $\begin{array}{l}\text { Tenoretic } \\
\text { Nifedipine } \\
\text { Hydralazine }\end{array}$ \\
\hline 2 & 45 & $F$ & $\begin{array}{c}\text { MCGN (type } \\
\text { unknown) }\end{array}$ & 27 & $135 / 90$ & $\begin{array}{l}\text { Atenolol } \\
\text { Methyldopa } \\
\text { Bendrofluazide }\end{array}$ \\
\hline 3 & 28 & $\mathrm{~F}$ & MCGN II & 24 & $130 / 80$ & $\begin{array}{l}\text { Cyclosporin } \\
\text { Atenolol }\end{array}$ \\
\hline 4 & 36 & $\mathbf{M}$ & MCGN II & $2 \cdot 2$ & 15()$/ 85$ & $\begin{array}{l}\text { Allopurinol } \\
\text { Captopril } \\
\text { Frusemide }\end{array}$ \\
\hline 5 & 30 & $\mathbf{F}$ & $\begin{array}{l}\text { Nephrotic } \\
\text { syndrome: } \\
\text { no biopsy }\end{array}$ & 14 & $15(0 / 80$ & $\begin{array}{l}\text { Cyclosporin } \\
\text { Prednisolone } \\
\text { Atenolol }\end{array}$ \\
\hline 6 & 43 & $\mathrm{~F}$ & $\begin{array}{l}\text { No biopsy: } \\
\text { normal renal } \\
\text { function }\end{array}$ & & $110 / 70$ & Anxiolytics \\
\hline 7 & 43 & $\mathbf{M}$ & MCGN II & 31 & $115 / 70$ & Tenoretic \\
\hline
\end{tabular}

Tenoretic $=$ atenolol $100 \mathrm{mg}$ and chlorthalidone $25 \mathrm{mg}$.
Ophthalmoscopic examination of these eyes revealed a few drusen (Fig. 2), but with no difference in

Table 2 Clinical details of cases without PLD

CaseAge Sex Glomerular Timesince Blood Current (yr) disease Diagnosis pressure medication (yr) $\quad(\mathrm{mm} \mathrm{Hg})$

\begin{tabular}{llllll}
\hline 8 & 51 & M & Membranous 2 & 180/100) Prednisolone
\end{tabular}
Atenolol $\begin{array}{lllllll}9 & 31 & \text { M } & \text { MCGN I } & 6 & 140 / 90 & \text { Nil }\end{array}$

10) 43 F MCGN I $99 \quad 140 / 85 \quad$ Nil

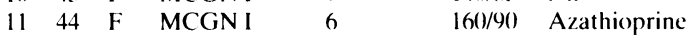
Prednisolone Atenolol

$12 \quad 73 \mathrm{M}$ Membranous 5

1349 F MCGN I

$140 / 70 \quad \mathrm{Ni}$

180/95 Prednisolone Azathioprine Atenolol Nifedipine $\begin{array}{llllll}14 & 39 & \mathrm{M} & \text { Membranous } 6 & 125 / 90 & \text { Bendrofluazide }\end{array}$ $1532 \mathrm{M}$ Membranous 2 1 $10 / 90$ Prednisolone Frusemide Spironolactone $\begin{array}{lllllll}16 & 25 & F & \text { MCGN I } & 1.5 & 150 / 90 & \text { Nil }\end{array}$

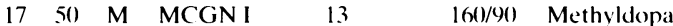
Frusemide Propranolol $\begin{array}{lllllll}18 & 29 & \mathrm{~F} & \text { Minimal } & 3 & 9(0 / 60) & \mathrm{Nil}\end{array}$

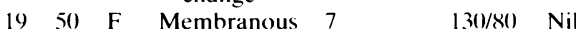


Table 3 Summary of patients

\begin{tabular}{llll}
\hline With partial lipodystrophy & & Without partial lipodystrophy & \\
\hline Type II MCGN & 4 & Type I MCGN & 6 \\
MCGN unclassified & 1 & Minimal change & 1 \\
End stage renal failure & 1 & Membranous & 5 \\
No renal lesion & 1 & & 12 \\
Total & 7 & & \\
\hline
\end{tabular}

frequency from that expected in normal age matched population. Similarly the fluorescein angiograms showed only a few hyperfluorescent spots corresponding to scattered drusen.

Of the seven patients with PLD (Table 4) five were found to have a very striking abnormality in the fundi (Figs. 3,4,5). There was a regular, bilaterally symmetrical distribution of discrete yellow spots, similar to drusen, more densely present posteriorly but spreading up to and beyond the equator. The lesions were not elevated, but were associated with some 'irregularity' of pigmentation. In the same five patients fluorescein angiography showed gross abnormalities correlating with the drusen-like appearance, and similar to that seen in the previous case report," with hyperfluorescence corresponding to the yellow lesions but with no leakage of fluorescein. There was some variation from case to case in the dimensions and distribution of the deposits, but there was symmetry within each case. The visual acuity was unaffected. Four of these five cases had biopsy proved type II MCGN, and the fifth was likely to be in this category on the basis of PLD and nephrotic syndrome, though no biopsy was ever taken.

Two patients with PLD had normal ophthalmoscopic and angiographic appearances. One had unclassified MCGN, and the other had no evidence of glomerular disease.

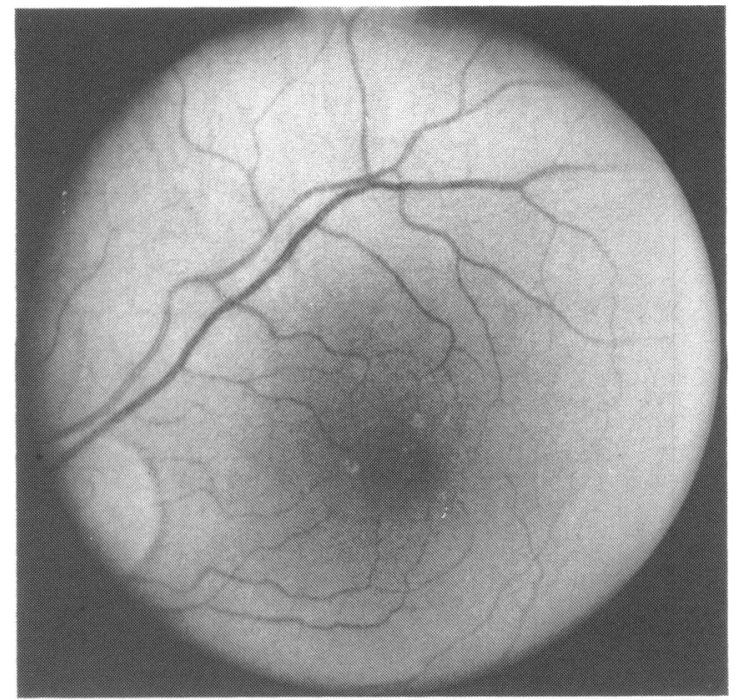

Fig. 2 Fundus photograph of case 18 showing scattered drusen at the posterior pole.

\section{Discussion}

We have described for the first time, to our knowledge, in this and in our recent publication an abnormal deposit in the eye at the level of Bruch's membrane and choriocapillaries in type II mesangiocapillary glomerulonephritis. Our findings in this communication support the hypothesis that the choriocapillaris - Bruch's membrane - retinal pigment epithelial complex may respond to disease in a similar way to the glomerulus.

The previously reported fundus changes seen in glomerular disease can be broadly divided into those associated with hypertension, those associated with vasculitis causing glomerulonephritis, those resulting from treatment of the renal lesion, and those

Table 4 Ophthalmic findings in cases with PLD

\begin{tabular}{|c|c|c|c|c|}
\hline \multirow[t]{2}{*}{ Case } & \multicolumn{2}{|c|}{ Visual acuity } & \multirow[t]{2}{*}{ Fundus examination } & \multirow[t]{2}{*}{ Fluorescein angiography } \\
\hline & $R$ & $L$ & & \\
\hline 1 & $6 / 6$ & $6 / 9$ & $\begin{array}{l}\text { Massive drusen-like deposits and mottled } \\
\text { pigmentation }\end{array}$ & Extensive hyperfluorescence in Bruch's membrane \\
\hline 2 & $6 / 6$ & $6 / 5$ & Drusen-like deposits and mottled pigmentation & $\begin{array}{l}\text { Few corresponding hyperfluorescent spots over } \\
\text { drusen }\end{array}$ \\
\hline 3 & $6 / 6$ & $6 / 6$ & $\begin{array}{l}\text { Massive drusen-like deposits and mottled } \\
\text { pigmentation }\end{array}$ & Extensive hyperfluorescence \\
\hline 4 & $6 / 9$ & $6 / 9$ & $\begin{array}{l}\text { Massive drusen-like deposits and mottled } \\
\text { pigmentation }\end{array}$ & Extensive hyperfluorescence \\
\hline 5 & $6 / 36$ & $6 / 24$ & $\begin{array}{l}\text { Massive drusen-like deposits and mottled } \\
\text { pigmentation }\end{array}$ & Extensive hyperfluorescence \\
\hline 6 & $6 / 6$ & $6 / 6$ & Normal & Normal \\
\hline 7 & $6 / 5$ & $6 / 5$ & $\begin{array}{l}\text { Massive drusen-like deposits and mottled } \\
\text { pigmentation }\end{array}$ & Extensive hyperfluorescence in Bruch's membrane \\
\hline
\end{tabular}




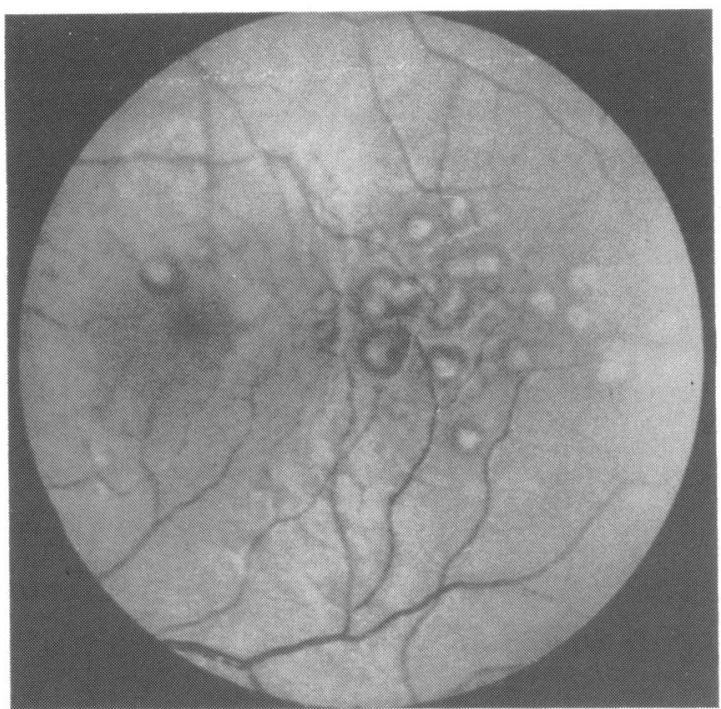

Fig. 3A

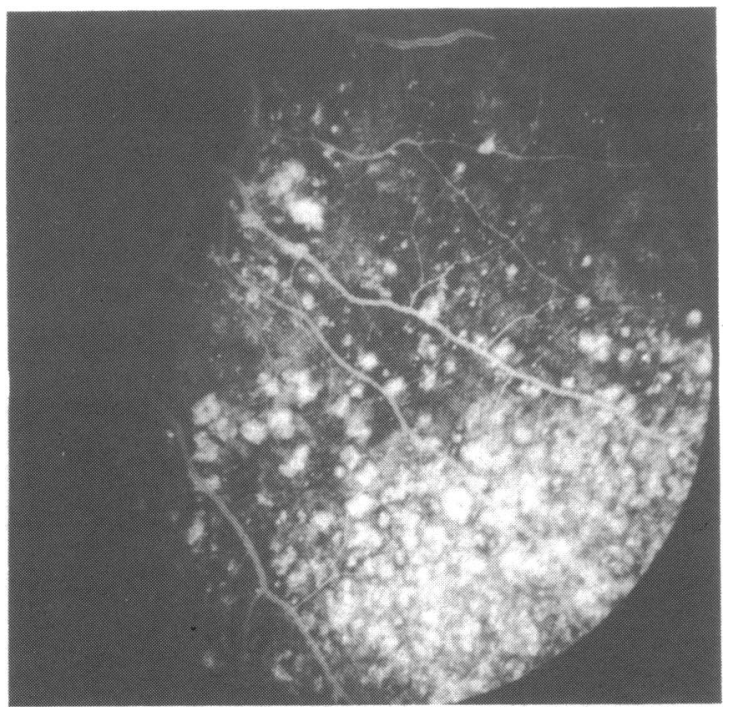

Fig. 3C

Fig. 3 A: Fundus photograph and B, C. fluorescein angiogram of case 4 showing large posterior pole deposits with a pigmented halo temporal to the macula, associated with intense focal hyperfluorescence which extends towards the equator.

considered to be specifically related to the renal lesion. ${ }^{5}$ In systemic hypertension the fundus abnormalities are well recognised, and they are described in renal patients. In accelerated hypertension infarcts of the retinal pigment epithelium, corresponding to failure of lobules of choriocapillaris to be perfused, termed Elschnig's spots, are described," but they

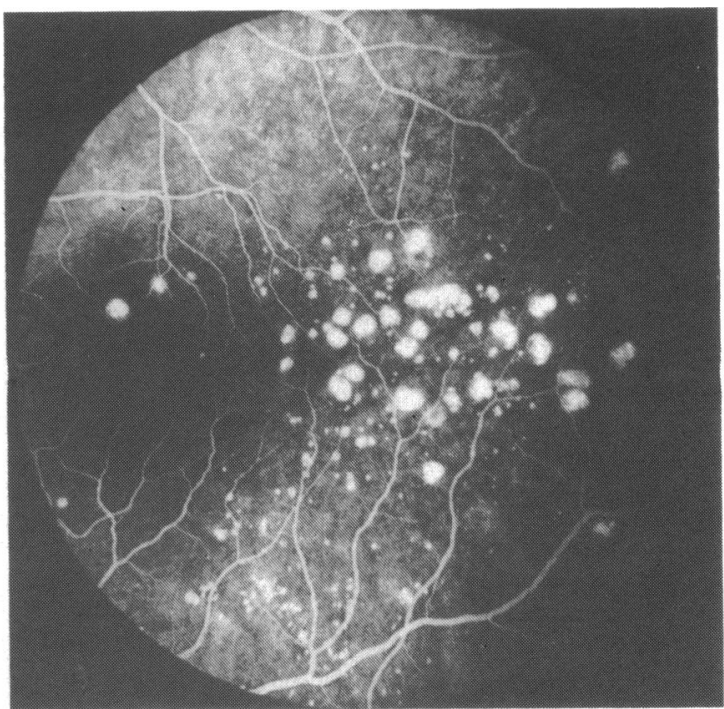

Fig. 3B

differ from the lesions we report in that they are much more widespread and are not associated with the focal pigment clumping seen in Elschnig's spots. In addition there is no history of visual disturbance in any of our patients, whereas if there were such widespread infarction of the retinal pigment epithelium visual symptoms would be expected.

A series of patients with glomerulonephritis with and without hypertension have been studied ophthalmoscopically. ${ }^{7}$ None of these showed any fluorescein angiographic abnormality, though the type of glomerulonephritis was not identified.

Vasculitis, such as is seen in systemic lupus erythematosus, may involve the renal circulation as well as the retinal and choroidal circulation, giving rise to cotton-wool spots, haemorrhages, swelling of the optic nerve head, and vascular occlusion. ${ }^{x-12}$ In the cases we have studied no features of vasculitis were present.

Ocular complications of chronic renal disease involve exudative retinal detachment ${ }^{13}$ and crystals of cystine in the cornea and retina, ${ }^{14}$ and the complications of treatment include cataract, raised intraocular pressure, opportunistic retinitis, ${ }^{15}$ and retinal microaneurysms. ${ }^{16}$

A numer of familial disorders are described which affect the eye and kidney. Those which involve the retina and choroid include Alstrom's syndrome, ${ }^{17-211}$ which comprises pigmentary retinopathy, obesity, diabetes mellitus, and nerve deafness, often associated with renal insufficiency; Alport's syndrome, ${ }^{21-23}$ which is characterised by lenticonus, spherophakia, sensorineural deafness, and a hereditary nephropathy and sometimes pigmentary 


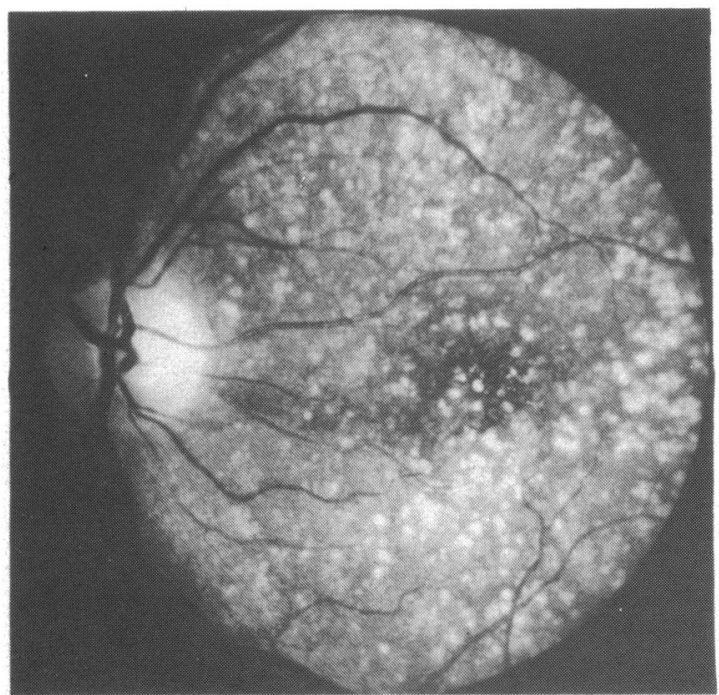

Fig. 4A

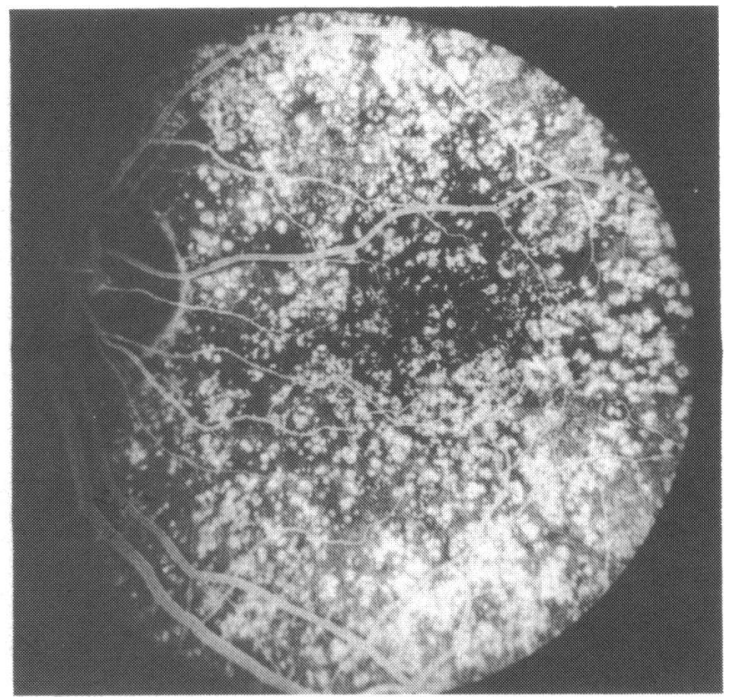

Fig. 4B

Fig. 4 A: Fundus photograph and B. fluorescein angiogram of case 10 showing scattered drusen-like deposits with intense hyperfluorescence.

retinopathy with or without subretinal and Bruch's membrane deposits; and adult polycystic kidney disease. ${ }^{2+} \mathrm{A}$ miscellaneous group of hereditary renal lesions associated with other fundus abnormalities, usually manifest as pigmentary retinopathies, are described. ${ }^{2-2 y}$ The only previous publications comparing pathology of the kidney and eye refer to

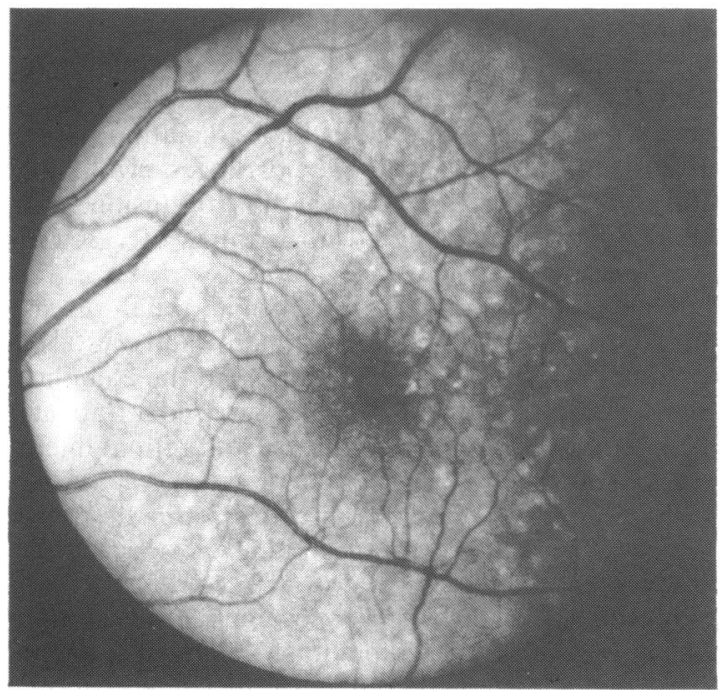

Fig. 5A patients with diabetes mellitus: microaneurysms have been described in the glomerulus ${ }^{31}$ and lesions resembling Kimmelsteil-Wilson nodules were described in the choroid. ${ }^{31}$

Bruch's membrane and the glomerular membrane are structurally homologous in that both are. selectively and directionally permeable,$^{32-34}$ with a positive

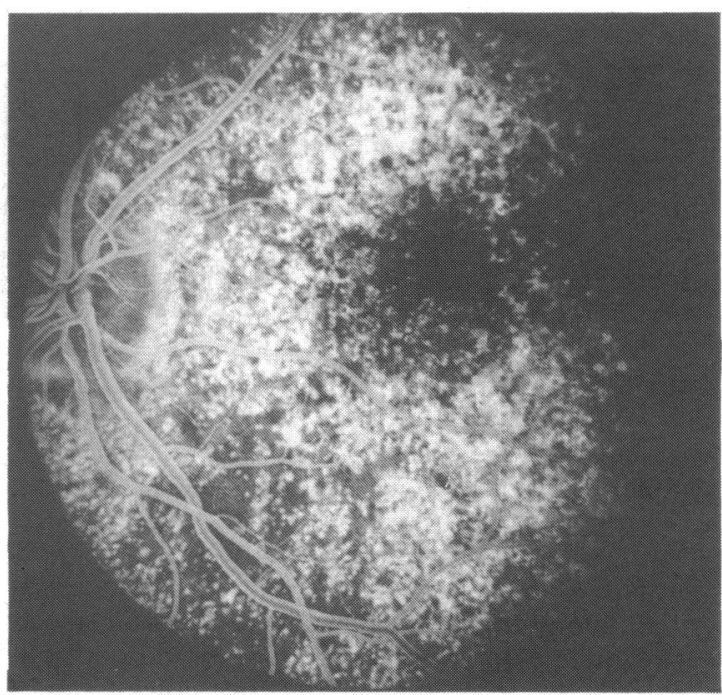

Fig. 5B

Fig. 5 A: Fundus photograph and B, fluorescein angiogram of case 19 showing extensive drusen-like deposits with hyperfluorescence. 
charge and a high heparan sulphate content. ${ }^{3-3 n}$ The two membranes differ in that the collagenous zones of Bruch's membrane make it much thicker than the glomerular basement membrane. Pathological changes in the renal glomerular basement membrane with similarities to those seen in Bruch's membrane are identifiable. In aging, the glomerular basement membrane is focally thickened, with the appearance of vesicles in the membrane ${ }^{37}$ similar to the aging changes of Bruch's membrane. ${ }^{3 \times}$ In aminoglycoside nephrosis, deposits with an ultrastructural similarity to drusen are present on the epithelial side of the glomerular basement membrane. ${ }^{3 \prime}$ Aminoglycoside toxicity has been used as an experimental means of creating drusen in the eye. " Breaks in the glomerular basement membrane, reminiscent of angioid streaks in Bruch's membrane, have also been described. ${ }^{+1}$

The nature of deposits in different types of glomerulonephritis differs histologically and presumably also pathogenetically. We suggest that, whatever the pathogenesis in MCGN type II, a similar setting pertains in Bruch's membrane, whereas in the other forms of glomerulonephritis this may not be the case. Recently an early case of MCGN II has been studied histopathologically. ${ }^{+2}$ It is interesting that the early lesion prior to the appearance of the dense deposit is lamellation of the lamina densa of the glomerular basement membranes, very reminiscent of the appearance seen in Alport's syndrome ${ }^{43}$ which is undisputably associated with a chorioretinal lesion. ${ }^{+45}$

Our findings suggest that, in patients with type II MCGN and PLD, chorioretinal changes similarly may parallel those found in the kidney. Although in all five patients with PLD and fundus changes the ophthalmic findings were very similar, the duration of renal disease ranged from 7 months to 31 years, and sequential observation is necessary to determine whether a lesion is static or variable with time. There is undoubtedly a structural and a pathological comparison to be drawn between the eye and the kidney, and further investigation of patients with glomerular disease may well shed light on the pathophysiological responses of the complex of choriocapillaris, Bruch's membrane, and retinal pigment epithelial. Similarly, study of the ocular responses may contribute to the understanding of the pathogenesis of the renal lesion.

\section{References}

1 Duvall J, Tso MOM. Cellular mechanism of resolution of drusen after laser coagulation. An experimental study. Arch Ophthalmol 1985: 103: 694-703.

2 Duvall-Young J, MacDonald MK. McKechnie NM. Fundus changes in (type II) mesangiocapillary glomerulonephritis simulating drusen: a histopathological report. Br J Ophthalmol 1989: 73: 297-302.
3 Churg J, Duffy JE. Bernstein J. Identification of dense deposit disease. Arch Pathol Lab Med 1979; 1403: 67-72.

4 Hepstinall RH. Pathology of the kidney. 2nd ed. Boston: Little, Brown. 1974.

5 Easterbrook M, Mortimer CB. Ocular signs in chronic renal failure. BrJ Ophthalmol 1970: 54: 724-30.

6 Klien BA. Ischaemic infarcts of the choroid. Am J Ophthalmol 1969; 66: 1069-74.

7 Miyake K. Maeda K, Imai T, et al. Vitreous fluorophotometry in diseased blood retinal barriers III. Chronic glomerulonephritis part 1. J Clin Ophthalmol (Japan) 1981; 35: 53-9.

8 Cordes FC. Aitken SD. Ocular changes in acute disseminated lupus erythematosus. Am J Ophthalmol 1947: 30: 1541-55.

9 Bishko F. Retinopathy in systemic lupus erythematosus. A case report and review of the literature. Arthritis Rheum 1972: 15: $57-63$.

10 Henkind P. Fundus lesions in connective tissue disease. Trans Ophthalmol Soc UK 1974: 94: 785-806.

11 Lanham JG, Barrie T, Kohner EM. Hughes GRVG. SLE retinopathy: evaluation by fluorescein angiography. Ann Rheum Dis 1982; 41: 473-8.

12 Jabs DA. Fine SL, Holchberg MC, Newman SA, Heiner GG, Stevens MB. Severe retinal vaso-occlusive disease in systemic lupus erythematosus. Arch Ophthalmol 1986: 104: 558-63.

13 Buchanan WS, Ellis PP. Retinal separation in chronic glomerulonephritis. Arch Ophthalmol 1964; 71: 182-6.

14 Kaiser-Kupfer MI. Camiso RC, Mincler DS. Gahl WA. Long term ocular manifestations of nephropathic cystinosis. Arch Ophthalmol 1986: 104: 706-11.

15 La Piana FG. Renal disease in clinical ophthalmology. In: Duane TD, Jaeger EA, eds. Philadelphia: Harper and Row, 1982: 5: ch 31 .

16 Hayasaka S, Kitaoka M, Mizunok K. Peripheral retinal microaneurysms in patients receiving hemodialysis. Retina 1986: 6: $113-8$.

17 Alstrom CH. Hallgren B, Nilsson CB. Retinal degeneration combined with obesity, diabetes mellitus and neuorogenous deafness. A specific syndrome (not hitherto described) from the Laurence-Moon-Barclet-Beedl syndrome. Acta Psychiatr Scand 1959; 34 (suppl): 129.

18 Millay RH. Weleber RG. Heckenliveley JR. Ophthalmic and systemic manifestations of Alstrom's disease. Am J Ophthalmol 1986: 102: 482-90.

19 Sebag J. Albert DL. Craft JL. The Alstrom syndrome. Ophthalmic, histopathologic, and renal ultrastructure. $\mathrm{Br} J$ Ophthalmol 1984; 68: 494-501.

20) Goldstein JL. Fialkow PJ. The Alstrom syndrome. Report of three cases with further delineation of the clinical, pathophysical and genetic aspects of the disorder. Medicine 1973: 52: 53-91.

21 Purriez P. Drets M. Pascale E. et al. Familial hereditary nephropathy (Alport's syndrome). Am J Med 1971: 49: 753-73.

22 Davies PD. Pigment dispersion in a case of Alport's syndrome. BrJ Ophthalmol 1970): 54: 557-61.

23 Peterson WS, Albert DM. Fundus changes in the hereditary nephropathies. Ophthalmology 1974: 78: 762-71.

24 Fairley KF, Leighton PW. Kinkaid-Smith P. Familial visual defects associated with polycystic kidney and medullary sponge kidney. Br Med J 1963: i: 1060-3.

25 Loken AL, Hanssen O. Halvorsen S, Jolster NJ. Hereditary renal dysplasia and blindness. Acta Paediatr Scand 1961: 50: $177-84$.

26 Senior B. Friedman AL. Braudou L. Juvenile familial nephropathy with tapetoretinal degeneration - a new oculo-renal dystropy. Am J Ophthalmol 1961: 52: 625.

27 Bsgouni B, Lolo-Spada G, Bietti S. Tapetoretinal degeneration with marginal corneal dystropy. Am J Ophthalmol 1968; 65: $53-60$.

28 Schimke RN. Hereditary renal-retinal dysplasia. Ann Intern Med 1969: 70: 735-44. 
29 Edwards WC, Grizzard WS. Tapeto-retinal degeneration associated with renal disease. J Pediatr Ophthalmol Strabismus 1981: 18: 55-7.

30) Nakamoto $Y$. Takazakura E. Hayakawa H. et al. Intraretinal microaneurysms in diabetic nephropathy. Lab Invest 1980; 42: 433-9.

31 Hidayat AA, Fine BS. Diabetic choroidopathy: light and electron microscopy observation of seven cases. Ophthalmology 1985: 92: $512-52$.

32 Hogan MJ. Electron microscopy of Bruch's membrane. Ophthalmology 1965; 69: 683-90.

33 Farquar MG. The primary glomerular filtration barrierbasement membrane or epithelial cells? Kidney Int 1975: 8: 197-211.

34 Carlson EC, Kenney MC. Morphological heterogenicity of isolated renal basement membranes. Renal Physiol 1980; 3: 288-97.

35 Pino RM, Essner E. Pino LC. Location and chemical composition of anionic sites in Bruch's membrane of the rat.J Histochem Cytochem 1982: 30: 245-52.

36 Rennke HG, Cotran RS. Venkatachalum MA. Role of the molecular charge in glomerular permeability. Tracer studies with cationised ferritins. J Cell Biol 1975; 67: 638-46.

37 Hayashide M. Yu BP, Masor EJ, Iwasaki K, Ikeda T. An electron microscopic examination of age related changes in the kidney. The influence of diet. Exp Gerontol 1986; 21: 53.5-53.
38 Feeney-Burns L. Ellersieck MR. Age related changes in the ultrastructure of Bruch's membrane. Am J Ophthalmol 1985: 100: $686-97$.

39 Kurtz SM. Feldman JD. Experimental studies on the formation of the glomerular basement membrane. J Ultrastruct Res 1962: 6: $19-27$.

40) El Baba F, Green WR, Fleischmann J, Finklestein D, de la Cruz ZC. Clinicopathologic correlation of lipidisation and detachment of the retinal pigment epithelium. Am J Ophthalmol 1986; 101: $576-83$.

41 Terasaki T, Sano M, Narita M, Tojo S. Ultrastructural study of the gaps of the glomerular basement membrane in $\lg \mathrm{A}$ nephropathy. Am J Nephrol 1986; 6: 443-9.

42 Sato H, Santo T, Seino J, et al. Dense deposit disease: its possible pathogenesis suggested by the observation of a patient. Clin Nephrol 1987: 27: 41-5.

43 Gubler M, Levy M, Broyer M, et al. Alport's syndrome. A report of 58 cases and a review of the literature. Am J Med 1981: 70: 493-505.

44 Govan JAA. Ocular manifestation of Alport's syndrome. A hereditary disorder of basement membranes? Br J Ophthalmol 1983: 67: 493-5()3

45 Thompson SM, Deady JP. Willshaw HE, White RHR. Ocular signs in Alport's syndrome. Eve 1987: 1: 146-53.

Accepted for publication + May 1989. 